\title{
A CROSS-CULTURAL ANALYSIS OF THE GENERIC STRUCTURE OF BUSINESS MANAGEMENT RE- SEARCH ARTICLES: THE METHODS SECTION ${ }^{1}$
}

\author{
Pilar Mur Dueñas ${ }^{2}$
}

\begin{abstract}
Many studies have focused on the analysis of each of the prototypical four sections of the research article (i.e. Introduction, Methods, Results, Discussion, Swales 1990). However, whereas some sections have been subject to a great deal of analysis, especially the Introduction, others have not attracted as much scholarly attention. That is the case of the Methods section. Nevertheless, it is believed that the particular organization and content of this section plays a crucial role in the production of a successful research article. The Methods sections of 24 research articles in Business Management written in English for an international readership and in Spanish for a local audience will be contrastively analysed in terms of their rhetorical organization. When comparing the results to those from previous analyses in the field of medicine, it stems that the Method sections in Business Management articles contains some specific steps which could be considered characteristic. Further, the results from the analysis of the comparable corpus indicate that there are certain differences in the extent of inclusion of some steps in the research articles in the two cultural contexts. It seems that both the disciplinary culture and the broad cultural context in which the research articles are written may shape and constraint the microstructure of the Methods sections.
\end{abstract}

Keywords: Research article, generic structure, methods section, disciplinary cultures, intercultural rhetoric.

Resumen: Muchos estudios se han centrado en el análisis de las cuatro secciones prototípicas del artículo de investigación (Introducción, Métodos, Resultados y Discusión, Swales 1990). Sin embargo, mientras algunas de estas secciones han sido el foco de numerosos estudios, en particular la Introducción, otras no han recibido tanta atención. Éste es el caso de la sección de métodos. A pesar de ello, se considera que el contenido y la organización estructural de esta sección juegan un papel importante en la consecución de un artículo de investigación adecuado. Este artículo analiza la sección de Métodos de 24 artículos de investigación en el campo de la Dirección y Organización de Empresas escritos en inglés para la comunidad internacional y en castellano para una audiencia local en relación a su organización retórica. Al comparar los resultados con los obtenidos en estudios previos, se constata que la sección de Métodos de los artículos de Dirección y Organización de Empresas contiene algunos steps (o sub-secciones retóricas) que le

1 Date of reception: March 2007.

Date of acceptance and final version: April 2007.

This research has been carried out within the framework of the research project InterLAE, financially supported by the Diputación General de Aragón (245-122) and the Ministerio de Educación y Ciencia ("El inglés y la ciencia: la voz del autor en la expresión y difusión del conocimiento científico. Análisis contrastivo de los recursos lingüísticos de la valoración en un corpus de textos académicos" HUM2005-03646).

2 Research Fellow, Departamento de Filología Inglesa y Alemana, Universidad de Zaragoza; $\square$ pmur@ unizar.es 
son propios. Por otra parte, los resultados obtenidos del análisis del corpus comparable indican que existen diferencias en la inclusión de ciertos steps en los artículos en los dos contextos culturales. Parece que tanto la comunidad disciplinar como el ámbito cultural global en los que se enmarcan los artículos de investigación determinan y constriñen la micro-estructura de la sección de Métodos.

Palabras clave: Artículo de investigación, estructura genérica, la sección de métodos, culturas disciplinares, retórica intercultural.

\section{INTRODUCTION}

Since Swales $(1981,1990)$ established the prototypical IMRD (Introduction, Methods, Results, Discussion) structure for the RA (research article), many linguists have undertaken the analysis of the rhetorical structure of this genre. Specially numerous have been the studies of the Introduction in RAs from several disciplines written in English by native and non-native speakers (i.e. Crookes 1985; Taylor and Tingguang 1991; Linderberg 1995; Nwogu 1997; Posteguillo 1999) as well as those which adopt a cross-cultural perspective (i.e. Duszak 1994; Burgess 2002). These studies generally conclude that the CARS model (i.e. Establishing a territory, Establishing a niche, Occupying the niche) proposed by Swales (1990) is not usually consistently applied, that is, that certain moves (sub-sections which fulfil a sub-rhetorical function) and/or steps (minor sub-sections within the latter) tend to be deleted in particular fields and/or in particular national cultural contexts and that the order of appearance of these moves and steps may be altered according to these two factors. These findings, thus, seem to indicate that the rhetorical structure of the RA is to some extent dependent on the discipline to which it belongs and/or the linguistic/cultural context in which it is written.

Although not as extensively as the Introduction, the other three sections of the RA have also been the object of some rhetorical and linguistic research. The RA Results section has been analysed in several disciplines: Sociology (Brett 1994), Medicine (Nwogu 1997; Williams 1999), Computer Science (Posteguillo 1999). Likewise, the Discussion section of RAs in Irrigation and Drainage (Hopkins and Dudley-Evans 1988), Dhemical Engineering (Peng 1987) and History, Politics and Sociology (Holmes 1997) RAs has also been subject of analysis. Finally, the section on which the present article will focus, Methods, seems to have attracted the least attention. Not only has research been less profuse in relation to the Results, Discussion and indeed Methods sections of the RA, but also cross-cultural studies of these three sections are very scarce, if at all found. The aim of this paper is to provide some evidence on the rhetorical organization of the Methods section in RAs, focusing on a corpus of texts from a single social science, Business Management, written in and for two different cultural contexts: the American international context and the Spanish national context.

As highlighted above, studies of the RA Methods sections are scarce. Nevertheless, a few studies have been found. Conduit and Modesto (1990) analyse a $\mathrm{PhD}$ thesis and 5 journal articles in the field of pharmacology at a generic and discoursal level. The pattern that arises from their generic analysis of the Materials/Methods section is: $[\mathrm{X} 1]^{\wedge}[\mathrm{Y}]^{\wedge}(\mathrm{Obs})$ where 
$\mathrm{X} 1$ = animate or inanimate participant, $\mathrm{Y}=$ process (lexical verb) and $\mathrm{Obs}=$ observation. This is a simplified pattern, which may only apply to this particular hard science; it may be hypothesized that a different, perhaps more intricate, section will result from the description of the procedures followed in a social science such as Business Management.

Another study which focuses on the Methods section of the RA is that of Nwogu (1997). His analysis of 30 texts from 5 medical journals reveals the following typical sequence of moves in this section of the RA:

Method

Move 4: Describing Data-Collection Procedure:

by (1) Indicating source of data

(2) Indicating data size

(3) Indicating criteria for data collection

Move 5: Describing Experimental Procedures:

by (1) Identification of main research apparatus

(2) Recounting experimental process

(3) Indicating criteria for success

Move 6: Describing Data-Analysis Procedures:

by (1) Defining terminologies

(2) Indicating process of data classification

(3) Identifying analytical instrument/procedure

(4) Indicating modification to instrument/

procedure.

(Nwogu 1997)

Table 1. Moves and constituent elements in the Methods section of medical RAs.

Finally, in a manual offering a general overview on how to write an RA in English internationally aimed at Spanish scholars, Coll García (2002) establishes a pattern of moves and steps to be included in the Methods sections. 


\section{Secuencia 1 $1^{\text {a }}$ : Presentación somera de los objetivos de la investigación}

\section{Secuencia $2^{\mathrm{a}}$ : Materiales}

Unidad informativa 2.1. Sujetos experimentales/muestra

Unidad informativa 2.2. Materiales propiamente dichos

Unidad informativa 2.3. Técnicas de experimentación

Unidad informativa 2.4. Equipo de investigación

Unidad informativa 2.5. Instrumentos

\section{Secuencia $3^{\mathrm{a}}$ : Diseño experimental}

Unidad informativa 3.1. Identificación

Unidad informativa 3.2. Descripción

Unidad informativa 3.3. Justificación / argumentación

Unidad informativa 3.4. Limitaciones / restricciones

\section{Secuencia $4^{\text {a }}$ : Formulación de hipótesis}

Secuencia $5^{\text {aa }}$ : Descripción del procedimiento experimental y del proceso de recogida de datos

Unidad informativa 5.1. Descripción procedimental del experimento

Unidad informativa 5.2. Descripción del proceso de recogida de datos

\section{Secuencia 6 ${ }^{\text {a }}$ : Procedimiento de análisis de datos}

Unidad informativa 6.1. Proceso de clasificación de datos

Unidad informativa 6.2. Variables

Unidad informativa 6.3. Procedimientos analíticos utilizados/tratamiento estadístico

Unidad informativa 6.4. Definición terminológica

Unidad informativa 6.5. Criterios seguidos para determinar el éxito o el fracaso del experimento o estudio.

(Coll García 2002)

Table 2. Sequences and information units in the Methods section of an RA in English.

These two patterns within the RA Methods will be taken as a point of departure for the analysis of this section in the corpus under analysis. However, given the general nature of Coll García's (2002) sequencing and the fact that Nwogu's (1997) pattern stems from the analysis of RAs in the medical field, it is expected that the micro-rhetorical structure to arise from analysing the BM RAs in the corpus will differ from them.

\section{THE CORPUS}

The corpus consists of 24 RAs written in English and in Spanish (140,000 words approximately) in the field of Business Management. The RAs selected for the corpus were 
taken from 4 different journals published during the years 2003 and 2004 in each of the two cultural contexts: Academy of Management Journal (AMJ), Strategic Management Journal (SMJ), Journal of Management (JM), and Journal of International Management (JIM) in the USA and Alta Dirección (AD), Dirección y Organización de Empresas (DyO), Revista Europea de Dirección y Economía de la Empresa (REDyEE) and Investigaciones Europeas de Dirección y Economía de la Empresa (IE) in Spain. Three RAs were selected from each of the journals. Only empirical RAs were compiled. The authors of the RAs selected for the corpus were based at a North American university in the case of the sub-corpus in English and at a Spanish university in the case of the sub-corpus in Spanish. So, although not necessarily native speakers of one or the other language, the authors of the RAs in English are scholars acquainted with the American academic world publishing internationally and the authors of the RAs in Spanish publish nationally in the Spanish context.

The RAs were downloaded from the Internet or scanned and subsequently converted into text format and carefully checked. The software Wordsmith Tools (4.0) was used to carry out the quantitative analysis of the corpus, which was supplemented with manual analysis.

\section{RESULTS AND DISCUSSION}

\subsection{The Methods section in business management RAs}

The two comprehensive analyses of the RA Methods section outlined above (Nwogu 1997 and Coll García 2002) have been taken into account along the analysis of this section in the business management RAs in English and Spanish in the corpus. However, as expected, some new steps have been found and some of the steps proposed by Nwogu (1997) and/or Coll García (2002) have not appeared in the corpus. As pointed out above, this may be the result of the different disciplinary nature of the RAs analysed by Nwogu (1997) and the ones analysed here and the general character of Coll García's (2002) sequence which is posited as applicable to a wide range of fields. Rather than outlining steps grouped under moves -as Nwogu (1997) and Coll García (2002) do-, only steps are outlined in relation to the business management RAs analysed. This is a result of not perceiving that steps are regularly encompassed under a superordinate move. The steps that have appeared at some point in the Methods sections of the business management RAs in the comparable corpus are:

1. Describing participants/the sample: the number of participants or firms that took part in the research is outlined together with some information about them, setting the context in which the research was carried out. Sometimes also the rationale and/or criteria in the selection of participants is included here.

(1A) A total of 92 call center CSRs employed by a financial services institution participated in the study. Of the 92, $20(22 \%)$ were men, $72(78 \%)$ were women, $40(43 \%)$ were non-minorities, and $52(57 \%)$ were minorities. (JM2) $)^{3}$

\footnotetext{
The information between brackets indicates the journal and the specific article from that journal from which the example has been drawn.
} 
(1B) Hemos seleccionado una muestra homogénea de empresas a nivel nacional, en el sentido de que son empresas que han recibido en algún momento una subvención por parte del CDTI (Centro para el Desarrollo Tecnológico Industrial) -considerándolas como PYMES innovadoras. (REDyEE2)

2. Describing data collection procedure: the steps followed in the distribution of questionnaires or in the selection of the sample tend to be indicated as well as the reasons for exclusion of some participants.

(2A) Hospital executives were pre-notified of the survey two weeks before the initial mailing. Survey instruments were mailed along with a letter of endorsement from the president of the hospital association, and instructions explaining the study. (JM3)

(2B) La configuración del listado de empresas se hizo a partir de la base de datos SABE (Sistema de Análisis de Balances Españoles), quedando la población definitiva conformada por 136 firmas. (DyO2)

3. Describing data collection results: the final number of participants or the final size of the sample is stated, after some exclusion procedure was imputed.

(3A) Including both rounds of surveys, firms representing 212 acquisitions responded to at least one survey. Both surveys were completed by 114 participants (39\%), with sufficiently complete information on the key variables completed by 77 firms $(27 \%)$, which provides the final sample for this study. (JM1)

(3B) Desde entonces y hasta febrero de 2002 se recibieron un total de 368 respuestas lo que supone un ratio de respuesta aceptable del 13,45\%. (IE2)

4. Outlining variables and measures: this step may be the consequence of the experimental nature of the RAs in the corpus. Managerial and practical cases seem to entail the establishment and analysis of particular, relevant variables; each variable is presented (and commonly defined) together with the measure by means of which it will be analysed.

(4A) To measure size-based imitation (trait imitation), we first determined the number of employees employed by each firm in our sample in 1989. We gathered data on firrn size using the database Research Insight. Then, for each given source, we averaged the sizes of all the firms that hired from it between 1987 and 1989. (AMJ3)

(4B) Para la medición del aprendizaje organizativo se ha optado por desarrollar una escala que reconozca el carácter multidimensional del aprendizaje y recoja de forma explícita información acerca de las cuatro dimensiones del aprendizaje identificadas teóricamente: adquisición de conocimiento, distribución, interpretación y memoria organizativa. (IE1)

5. Describing data-analysis procedure: rather than indicating the particular variable(s) and measure(s) analysed, in this step more general statements about the methodological process are made. 
(5A) Our analyses proceeded in two stages. Initially, we conducted preliminary analyses, assessing the overall robustness of the basic theoretical model proposed and tested by Jackson and Dutton (1988). We contrasted a parsimonious one-factor model against the two-factor theoretical model of threat discrimination and opportunity discrimination, using all 12 items identified by Jackson and Dutton. (SMJ3)

(5B) La configuración de los diferentes grupos (competitivas y no competitivas) a partir de la valoración de la posición relativa de las empresas en función de los parámetros propuestos, se realizará siguiendo la metodología que exponemos a continuación:

1. Calcular, para cada una de las 53 empresas de la muestra y los cuatro años de análisis, los valores medios de cada uno los parámetros clasificadores (cifra de negocios y rentabilidad financiera).

2. Obtención de dos conglomerados de empresas (competitivas y no competitivas) mediante la aplicación del análisis cluster a los resultados obtenidos en el paso anterior. (IE3)

6. Reference to previous literature: citations are included along the RA, including the Methods section.

(6A) Patterns of favor exchange, status, and productivity may be driven, in part, by access to resource (e.g., Biau 1963; Long 1998). (AMJ2)

(6B) La calidad percibida la entendemos, siguiendo a Zeithami (1988), como un juicio subjetivo del consumidor sobre la excelencia o superioridad de un producto. (REDyEE1)

7. Reference to past research which follows a similar methodological procedure: it seems important within this discipline to base one's research not only upon previous work and previous literature but also upon previously tested empirical techniques. ${ }^{4}$

(7A) Several other scholars have recently used the same measure of Internet firm performance (Kotha, Rajgopal and Rindova 2001). The measure has also been used in the study of other new firms in emerging economic sectors, such as biotechnology (DeCarolis and Deeds, 1999; Stuart et al 1999) and in the study of a diversified sample of IPO firms (Welboume and Andrews 1996; Welboume and Cyr 1999). (SMJ1)

(7B) Posteriormente, se realizó la codificación de la información contenida en esos artículos, para lo que se utilizó la técnica metodológica del análisis de contenido (Krippendorf 1980). (AD3)

8. Claiming validity: business management scholars tend to make claims that refer to the possible biased measures and analyses and how they took those issues into account and managed to solve them. This is a clear illustration of the readers' potential

\footnotetext{
$4 \quad$ In JM1 the following statement is made "[w]hen possible, existing measures were used with modifications; otherwise, we developed new measures".
} 
negatability of claims and how it leads scholars to anticipitate any possible negative opinions on the part of readers. Also, scholars in this discipline try to claim validity by justifying the sample taken and/or the variables and measures used.

(8A) In addition to, or instead of, technological activity, a JV may be expected to play a role in the manufacturing and/or marketing of a biotechnology product. We therefore control for the original purpose of the JV by examining whether the JV has a manufacturing or marketing agreement. (JIM2)

(8B) Ante la imposibilidad de analizar todas las firmas, optamos por seleccionar las de mayor tamaño, entre otras razones porque la creación de una alianza estratégica requiere la disponibilidad de un mínimo de recursos, siendo el tamaño un índice de esta cualidad. (DyO2)

9. Reference to past research (consistency): some results obtained are compared to previous work to seek consistency and, hence, credibility. As shown in the Tables below this is a very uncommon step in this section of business management RAs. It is far more common in the Discussion section. Nevertheless, it has also been included in this section in a few occasions in the sub-corpus in English.

(9A) This mean value suggests that employees believed, on the average, that they gave more than they received in their favor exchanges with other employees, a finding that is consistent with previous research on egocentric accounting biases in exchange relationships (e.g., Ross and Sicoly 1979). (AMJ2)

10. Indicating a finding: statements of findings in the Methods section refer to marginal analyses, such as for instance, comparing certain variables in fully completed questionnaires (and hence included in the sample) and uncompleted ones (and thus excluded from the sample), or findings regarding the characteristics of the firms or participants in the sample.

(10A) These means were not significantly different. Differences between respondents to both surveys and non-respondents to either survey for firm-level measures of size, return on investment and sales growth were also not significant. (JM1)

(10B) Respecto al tamaño de la empresa, analizando en primer lugar el volumen de facturación, éste evoluciona de forma muy favorable. Así, en el momento de su constitución - primer año de actividad-, la empresa que más facturó fue de 860 millones al año, pasando a 8350 millones la empresa que más facturó en 1999. En el número de empleados se da, también, un incremento notable de los mismos con el paso del tiempo, [...] (REDyEE2)

11. Aim/structure of the section: it is usually included at the beginning of the section to introduce and guide the reader along it.

(11A) The following section will elaborate the process undertaken for data collection and the statistical methodology used in the testing of the hypotheses. (JIM1)

(11B) En este apartado procederemos a explicar de forma breve las principales consideraciones en relación al proceso de recogida y análisis de información necesario para este estudio. (AD1)

Two further steps have been found only once in the whole corpus in the Methods sections and, thus, have not been included in the tables below: "Restatement of hypothesis" 
(example 12) and "Claiming centrality" (example 13). They tend to be more common in the Results section (in which the origial statement of hypotheses is further away) and the Introduction section (in which the research is justified in terms of importance, novelty, etc.), respectively.

(12) Hypotheses 2 and 6 predict a curvilinear effect (inverted U-shaped) of perceived imbalance on productivity. (AMJ2)

(13) El sector azulejero español ha mostrado un gran dinamismo, como se aprecia en la gran cantidad de exportaciones realizadas y en la importante evolución tecnológica iniciada en la segunda mitad de los años ochenta, que ha generado productos de una gran calidad y diseño. Este gran dinamismo ha hecho necesario el desarrollo de organizaciones e instituciones de apoyo a las empresas del sector. (DyO1)

Some of the steps outlined above are similar to the ones proposed by these two scholars. Step 1 above could be considered parallel to Nwogu's (1997) step "Indicating source of data" and to Coll García's (2002) information unit "Sujetos experimentales/muestra". Step 2, "Describing data collection procedure", which constitutes move 4 in Nwogu's (1997) pattern and Coll García's (2002) fifth sequence, is seen here as a more concise step in which only how the data was obtained (by means of a questionnaire, through a database, etc.) is coded. Step 3, "Describing data collection results", includes Nwogu's (1997) step "Indicating data size" plus the criteria for excluding some participants. Step 8, "Claiming validity", is seen as a general step in that validity can be claimed by justifying criteria of inclusion and exclusion from the sample, by arguing appropriateness of measures, etc.; in that sense, it may be considered to be related to Nwogu's (1997) step "Indicating criteria for success" and Coll García's (2002) steps “Justificación/argumentación" and "Limitaciones/restricciones". On the other hand, some moves in Nwogu's (1997) and Coll García's (2002) formats have not been regularly found in the corpus: "Describing experimental procedures", "Formulación de hipótesis" and "Diseño experimental"; neither have been found some of the steps they put forward: "Indicating process of data classification", "Identifying analytical instrument/ procedure", "Indicating modification to instrument/procedure", which may be specific to medical research, "Defining terminologies", "Definiciones terminológicas", which have been found to appear in the Introduction section in the comparable corpus, "Técnicas de investigación", "Instrumentos" and a few more. Finally, some steps have been discerned which were not included in their patterns: "Outlining variables and measures", 5 "Reference to previous literature" and "Reference to past research which follows a similar methodological procedure". On the whole, then, the Methods sections of business management RAs seem to share certain similarities in the type of information coded with medical RA Methods sections, but also to have their own characteristic sub-rhetorical particularities.

\subsection{Comparing English and Spanish business management RA Methods sections}

Although most steps outlined above have been found both in the sub-corpus in English and in the sub-corpus in Spanish, some of them have not been included to the same extent in the two sub-corpora. The following two tables summarise the extent of (non)inclusion

Coll García (2002) establishes the information unit "variables", which is slightly different, since it has been found that in the BM RAs variables are accompanied by the corresponding measures. 
of the steps presented above in the business management RAs in English (Table 3) and in Spanish (Table 4):

\begin{tabular}{|l|c|c|c|c|c|c|c|c|c|c|c|c|}
\hline & 1 & 2 & 3 & 4 & 5 & 6 & 7 & 8 & 9 & 10 & 11 & TOTAL \\
\hline AMJ1 & + & + & + & + & & & + & & & & & 5 \\
\hline AMJ2 & + & + & & + & & + & + & + & + & + & & 8 \\
\hline AMJ3 & + & + & + & + & + & + & + & + & & & & 8 \\
\hline JM1 & + & + & + & + & + & + & + & + & & + & & 9 \\
\hline JM2 & + & & & + & & + & + & + & & & & 5 \\
\hline JM3 & + & + & & + & + & + & + & + & + & & & 8 \\
\hline SMJ1 & + & + & + & + & + & & + & + & & & & 7 \\
\hline SMJ2 & + & + & & + & + & + & + & + & & & & 7 \\
\hline SMJ3 & + & + & + & + & + & + & + & + & & + & & 9 \\
\hline JIM1 & + & + & + & + & + & + & + & + & & & + & 9 \\
\hline JIM2 & + & + & + & + & & + & + & + & & & & 7 \\
\hline JIM3 & + & + & + & + & + & + & + & + & & + & & 9 \\
\hline TOTAL & 12 & 11 & 9 & 12 & 8 & 10 & 12 & 11 & 2 & 4 & 1 & 9 \\
\hline
\end{tabular}

Table 3. Steps in the Methods section of the business management RAs in English.

\begin{tabular}{|l|c|c|c|c|c|c|c|c|c|c|c|c|}
\hline & 1 & 2 & 3 & 4 & 5 & 6 & 7 & 8 & 9 & 10 & 11 & TOTAL \\
\hline $\mathrm{AD} 1$ & + & + & + & & + & & & & & & + & 5 \\
\hline $\mathrm{AD} 2$ & + & + & + & & + & & & + & & & & 5 \\
\hline $\mathrm{AD} 3$ & + & + & & & + & & + & + & & & + & 6 \\
\hline $\mathrm{DyO} 1$ & + & + & & + & & & & + & & + & + & 6 \\
\hline $\mathrm{DyO} 2$ & + & + & + & + & & & & + & & & & 5 \\
\hline DyO3 & + & + & + & + & & + & + & & & & & 6 \\
\hline $\begin{array}{l}\text { REDy- } \\
\text { EE1 }\end{array}$ & + & + & + & + & & + & + & + & & & & 7 \\
\hline $\begin{array}{l}\text { REDy- } \\
\text { EE2 }\end{array}$ & + & + & & + & & + & & & & + & & 5 \\
\hline $\begin{array}{l}\text { REDy- } \\
\text { EE3 }\end{array}$ & + & + & + & + & + & + & + & + & & + & & 9 \\
\hline IE1 & + & + & + & + & & & + & + & & & & 6 \\
\hline IE2 & + & + & + & & & & & & & + & & 4 \\
\hline IE3 & + & + & + & + & + & + & & + & & + & & 8 \\
\hline TOTAL & 12 & 12 & 9 & 8 & 5 & 5 & 5 & 8 & 0 & 5 & 3 & \\
\hline
\end{tabular}

Table 4. Steps in the Methods section of the business management RAs in Spanish.

In the sub-corpus in English "Method(s)" seems to be the preferred heading under which this section is included, appearing in 8 RAs. Other headings found in this section 
are "Research method", "Research methodology", "Research data and methodology" and "Methodology". Under these headings many diverse sub-headings have been included. All Methods sections in English have included at least one sub-heading, which frequently, though not necessarily, indicate the step(s) covered. It has been found, for instance, that the sub-heading "Analyses" is not necessary for the step "Describing data-analysis procedure" to appear in the Methods section. It is interesting to note that despite the diversity in the sub-headings used ("Participants and procedures", "Measures", "Sample", "Research setting", "Analysis", "Non-response bias", "Data collection", "Sample selection", "Measurement of variables", "Statistical methodology", "Dependent variable measures", "Independent variable measures"), the range and number of steps included in this section of the business management RAs in English is very similar. With the exception of AMJ1 JM2, Methods sections in English present 7 to 9 steps. Three steps appear to be compulsory in the Methods sections of business management RAs published in English internationally as they have been included in all RAs in the corpus: "Describing participants/the sample", "Outlining variables and measures" and "Reference to past research which follows a similar methodological procedure". Two other steps have been found in all RAs in the corpus but one: "Describing data collection procedure" and "Claiming validity".

In the business management RAs in Spanish the heading "Metodología" has been most extensively used, appearing just in 5 RAs. Similar headings have been used in 2 RAs "Metodología de la investigación" and "Metodología y universo considerado". Other headings used are "Diseño de la investigación y metodología", "Materiales y métodos" and "Estudio empírico". Two RAs presented no general heading (DyO2, REDyEE1) and five RAs presented no sub-headings, thus not providing the reader with visible clues about the changing communicative purpose of the section. ${ }^{6}$ In addition, the range and number of steps included in the Spanish RA Methods sections have been found to be less homogenous than in the English Methods sections. The number of steps included range from 5 to 9 steps. Whereas in the English sub-corpus steps 1 to 8 (the most frequent ones) in the Methods sections were included in 8 to 12 RAs in the Spanish sub-corpus, they were included in 5 to 12 RAs. Two steps have been included in all Spanish RAs, "Describing participants/ the sample" and "Describing data collection procedure". Other seemingly compulsory steps in the English RA Methods section, such as "Outlining variables and measures" and "Reference to past research which follows a similar methodological procedure", cannot be considered so in the Spanish sub-corpus, as they appeared only in 8 and 5 Spanish RAs, respectively. In fact, the greatest difference between both sub-corpora in the rhetorical micro-structure of this section has been found in the extent of inclusion of step 7 "Reference to past research which follows a similar methodological procedure". Whereas all Methods sections in English included citations of previous work which successfully followed the methodological procedure presented, only 5 RAs in Spanish included this type of references. The second greatest difference refers to step 6 "Reference to previous literature", which

\footnotetext{
6 The scarcer number of headings and sub-headings in the Spanish sections of the RA than in the ones in English can be a consequence of the reader-responsible style and the writer-responsible style (Hinds 1987) that tend to characterise texts in the two cultural contexts. In the Spanish BM RAs, readers seem to be provided with less guidance as regards the changing communicative purpose of the RA and its internal micro-structure, which would be in line with the alledgedly reader-responsible style favoured in the Spanish language and context.
} 
has been included in fewer RAs in Spanish than in English; 10 RAs in English made also reference or reviewed the literature in the field, but only 5 RAs in Spanish included any such references. Also significant is the different extent of inclusion of step 8 "Claiming validity", which was found in 11 RAs in English and in 8 RAs in Spanish.

\section{CONCLUDING REMARKS}

When contrasting the rhetorical micro-structure of the Methods sections in RAs from different disciplines, some differences arise. In this particular case, some of the steps which are found to be characteristic of the business management RA Methods sections have not been reported in previous studies of this section from RAs in other disciplines, mainly in the medical field. At the same time some of the steps which were reported in this previous research in relation to the medical RA Methods sections are not found in the comparable corpus of business management RAs. Thus, this study provides more evidence on the already highlighted issue that the disciplinary communities constrain the rhetorical conventions of academic knowledge production (Breivega et al. 2002; Dahl 2004; Hyland 2000, 2005, among others).

Further, when the rhetorical micro-structure of the Methods sections in English and in Spanish within the same discipline is compared, some differences also come out. Whereas most steps are found in the Methods sections of both business management RAs in English and in Spanish, the frequency of inclusion of some of them is rather different. For instance, "Reference to past research which follows a similar methodological procedure", "Reference to previous literature", "Claiming validity" and "Describing participants/the sample" are steps more commonly included in the English RAs; in fact, some of these steps are found in all RAs in the English corpus. Also, in general, RA Methods sections in English seem to be more homogenous in terms of the type and number of steps included than those in English.

The different socio-cultural context in which the RAs are written and published may account for these rhetorical differences. In order for research to be published internationally in English in the field of BM, it may need to follow well-attested methodological procedures that may have been used in past research. Some departures from previously used methods may also be accepted as long as they are indicated and justified. In this context it seems crucial that both in relation to the theoretical framework and in relation to the methodological procedure, international BM RAs give a sense of continuation within the field, carefully rooting their research in already published work. This grounding of theory and methodology on previous studies seems to be less important in the case of BM RAs published in a national context, in which also the feeling of contributing disciplinary knowledge to the community may not be as stark. In addition, citing past research which follows similar methodological procedure(s) also contributes to justifying the research and to convincing the reader of its credibility. Similarly, it is relevant that the step "Claiming validity" is present in more RAs in English than in RAs in Spanish. Because the competitiveness to get a BM RA internationally in English is getting fierce (much more than getting it published nationally in the Spanish context), a persuasive strategy may be to explicitly 
draw the readers' attention upon the validity of the measures and variables to be used, which entails the validity of the subsequent results.

In conclusion it appears that both the small (i.e. disciplinary) and big (i.e. broad, national) cultures (Atkinson 2004) in which the business management RAs are written exert an influence on the type of information to be included in the Methods section, and for that matter, on the way scientific knowledge is created, organised and distributed among academic peers. It is believed that text-based intercultural analyses such as the one presented here may help unveil significant rhetorical differences in academic writing produced in different contexts, which, in turn, may prove valuable for scholars wishing to publish their research in different (inter)national contexts.

\section{REFERENCES}

AtKinson, D. 2004. "Contrasting rhetorics/contrasting cultures: why contrastive rhetoric needs a better conceptualization of culture". Journal of English for Academic Purposes 3, 4: 277-289.

Breivega, K. R., T. Dahl and K. Fløttum. 2002. "Traces of self and others in research articles. A comparative pilot study of English, French and Norwegian research articles in medicine, economics and linguistics". International Journal of Applied Lingusitics 12, 2: 218-239.

BRETT, P. 1994. "A genre analysis of the results section of sociology articles". English for Specific Purposes 13, 1: 47-59.

Burgess, S. 2002. "Packed houses and intimate gatherings: Audience and rhetorical strategies”. Academic Discourse. Ed. John FlowERDEw. London: Longman. 196-225.

Coll García, J. F. 2002. "La sección de métodos". Cómo escribir un artículo de investigación en inglés. Coord. I. ForTANET. Madrid: Alianza. 84-120.

Conduit, A. M. and D. V. Modesto. 1990. "An investigation of the generic structure of the Material/Methods section of scientific reports". ARAL Series S 6: 109-134.

Crookes, G. 1985. "Towards a validated analysis of scientific text structure". Applied Linguistics 7, 1: 57-70.

DAHL, T. 2004. "Textual metadiscourse in research articles: A marker of national culture or of academic discipline?”. Journal of Pragmatics 36: 1807-1825.

DuszaK, A. 1994. "Academic discourse and intellectual styles". Journal of Pragmatics 21: 291-313.

Hinds, J. 1987. "Reader versus writer responsibility: A new typology". Writing across Languages: Analyses of L2 Texts. Eds. U. Connor and R. Kaplan. Reading MA: Addison-Wesley. 141-167.

Holmes, R. 1997. "Genre analysis, and the social sciences: An investigation of the structure of research article discussion sections in three disciplines". English for Specific Purposes 16, 4: 321-337. 
Hopkins, A. and T. Dudley-Evans. 1988. "A genre-based investigation of the discussion sections in articles and dissertations". English for Specific Purposes 7: 113-121.

Hyland, K. 2000. Disciplinary Discourses: Social Interactions in Academic Writing. London: Longman. . 2005. Metadiscourse. London: Continuum.

LinDERBERG, A.C. 1995. "Tenses, modals and rhetorical structuring in research articles in finance, management and marketing: An exploratory study of introductions". Organization in Discourse. Proceedings from the Turku Conference. Anglicana Turkuensia 14. Ed. B. WÅrvick, S-K. TANSKANEN and R. Hiltunnen. 361-369.

Nwogu, K. N. 1997. "The medical research paper: Structure and functions". English for Specific Purposes 16, 2: 119-138.

Peng, J. 1987. "Organizational features in chemical engineering research articles". English Language Research Journal 1: 79-116.

Posteguillo, S. 1999. "The schematic structure of computer science research articles". English for Specific Purposes 18, 2: 139-160.

SwALES, J. 1981. Aspects of Article Introductions. Birmingham, UK: The University of Aston: Language Studies Unit.

. 1990. Genre Analysis: English in Academic and Research Settings. Cambridge: Cambridge University Press.

Taylor, G. and C. Tingguang. 1991. "Linguistic, cultural and subcultural issues in contrastive discourse analysis: Anglo-American and Chinese Scientific Texts". Applied Linguistics 12, 3: 319-336.

Williams, I. A. 1999. "Results section of medical research articles: analysis of rhetorical categories for pedagogical purposes". English for Specific Purposes 18, 4: 347-366.

\section{References WITHIN THE EXAMPLES}

Biau, P.M. 1964. Exchange and Power in Social Life. New York: Wiley.

DeCArolis, D.M. and D.L. DeEds. 1999. "The impact of stock and flows of organizational knowledge on firm performance: An empirical investigation of the biotechnology industry". Strategic Management Journal 20 (10): 953-968.

JACKSON, S. and J. DutTON. 1988. "Discerning threats and opportunities". Administrative Science Quarterly, 33: 370-387.

Kotha, S., S. Rajgopal and V. Rindova. 2001. "Reputation building and performance: an empirical analysis of the top-50 pure Internet firms". European Management Journal, 22 (8): 793-804. 
KripPendorf, K.1980. Content Analysis: An Introduction to its Methodology. Newbury Park, CA: Sage Publications. Sage Commtext Series.

LONG, R. 1998. "Research productivity of graduates in management: Effects of academic origin and academic affiliation". Academy of Management Journal 41: 704-715.

Ross, M. and F. Sicoly. 1995. "Psychological contracts and OCB: The effect of unfulfilled obligations on civic virtue behaviour". Journal of Organizational Behavior, 16: 289-298.

Wellbourne, T.M. and A.O. Andrews. 1996. "Predicting performance of initial public offerings: Should human resource management be in the equation?" Academy of Management Journal, 39: 891-919.

Wellbourne, T.M. and L.A. Cyr. 1999. "The human resource executive effect in initial public offering firms". Academy of Management Journal 42: 616-629.

Zeithaml, V. A. 1988. "Consumer perceptions of price, quality and value: A means-end model and synthesis of evidence". Journal of Marketing 54: 2-22. 